\title{
ANALISIS PENERAPAN E-SYSTEM PERPAJAKAN PADA WAJIB PAJAK PRIBADI TERHADAP PELAKSANAAN SELF-ASSESMENT SYSTEM DALAM MEMENUHI KEWAJIBAN PERPAJAKAN
}

\author{
Helen Widjaja dan Arthur Jaya Siagian \\ Fakultas Ekonomi Universitas Tarumanagara \\ Email: helenpww@gmail.com dan Email: arthur_siagian@yahoo.co.id
}

\begin{abstract}
E-sytem Modernization taxation is using information technology to the esystem is expected to facilitate taxpayers to report tax. With the use of advanced electronic information in Taxation is expected to improve service to the taxpayer, both in terms of quality and time to be more effective. Objective, is to determine the effectiveness of the use of e-taxation system in the form of e-registration,e-spt, e-filing, e-billing affect the fulfillment of tax obligations personal taxpayers. Research methods used in this study is a research approach Explorative. This research was conducted through interviews, observation, and documentation on KPP Pratama Kebayoran Baru Tiga South Jakarta. The results of this study indicate that the e-system on KPP Pratama Kebayoran Baru Tiga effectively and efficiently.
\end{abstract}

Keywords: E-system, e-Registrasion,e-STP , e-Filling, E-Billing

\begin{abstract}
Abstrak: E-sytem Perpajakan merupakan Modernisasi perpajakan dengan menggunakan teknologi informasi yang diharapkan dengan e-system dapat mempermudah wajib pajak untuk melaporkan pajak. Dengan penggunaan Terknologi Informasi dalam Perpajakan diharapkan dapat meningkatkan pelayanan terhadap Wajib Pajak, baik dari segi kualitas maupun waktu sehingga lebih efektif. Tujuan Penelitian, ialah untuk mengetahui efektivitas penggunaan $e$-system perpajakan berupa $e$-registration, $e$-spt, $e$-filing, $e$-billing berpengaruh terhadap pemenuhan kewajiban perpajakan wajib pajak pribadi. Metode Penelitian yang di gunakan pada penelitian ini adalah pendekatan penelitian Eksploratif. Penelitian ini dilakukan dengan wawancara, observasi, dan dokumentasi pada KPP Pratama Kebayoean Baru Tiga Jakarta Selatan. Hasil Penelitian ini menunjukan bahwa $e$ system di KPP Pratama Kebayoran Baru Tiga efektif dan efisien.
\end{abstract}

Kata Kunci : E-system,e-Registrasion,e-STP , e-Filling, E-Billing

\section{PENDAHULUAN}

Negara Indonesia dalam menjalankan pemerintahan dan pembangunan membutuhkan anggaran yang besar, Dimana sumber pendanaan terbesarnya ialah berasal dari pajak yang bersumber dari Anggaran pendapatan dan belanja negara(APBN). Seperti yang juga di umumkan oleh menteri keuangan awal tahun 2016 ini bahwa realisasi penerimaan pajak tahun 2015 mencapai Rp. 1.235,8 triliun atau 83\% dari target penerimaan pajak yang ada dalam APBNP 2015 sebesar Rp 1.489,3 triliun. Maka dapat diketahui bahwa sumber pendapatan terbesar negara Indonesia berasal dari pajak, sehingga Indonesia akan kesulitan untuk berkembang jika pajak yang di dapatkan jauh dari realisasi penerimaan. Untuk mencapai target pajak ini, peran wajib pajak dalam sistem pemungutan pajak sangat menentukan. Peneriman pajak yang optimal dapat dilihat dari berimbangnya tingkat penerimaan aktualnya. oleh karena 
itu, pelaksanaan kewajiban perpajakan dalam membayar pajak merupakan faktor penting yang mempengaruhi sumber penerimaan pajak negara dari wajib pajak.

Tuntutan akan peningkatan penerimaan perpajakan negara, peningkatan kesadaran dalam melaksanakan kewajiban perpajakan serta perbaikan-perbaikan dan perubahan mendasar dalam aspek perpajakan menjadi alasan dilakukanya reformasi perpajakan. Dalam rangka meningkatkan kemandirian bangsa dalam membiayai pembangunan nasional dengan jalan lebih mengoptimalkan segenap kemampuan dalam negeri terutama di bidang perpajakan maka pemerintah melakukan reformasi kebijakan yang membuat official assesment system berubah menjadi self assesment system yang menuntut kesadaran dan kepatuhan yang tinggi dari wajib pajak. Oleh karena itu selain meningkatkan Jumlah wajib pajak, faktor kesadaran dan kepatuhan sangatlah penting untuk menggenjot target penerimaan Negara yang cukup besar khususnya dalam RAPBNP tahun 2016 saat ini. Kelemahan self assesment system yang memberikan kepercayaan kepada masyarakat untuk menghitung,membayar,dan melaporkan sendiri pajak terutang ternyata dalam prakteknya sulit berjalan sesuai dengan yang di harapkan, bahkan disalahgunakan (Tarjo dan Indrawati,2006).

Salah satu langkah yang diambil pemerintah untuk meningkatkan pendapatan perpajakan yaitu dengan melakukan modernisasi pada sistem administrasi perpajakan. Oleh karena itu, Direktorat Jendral Pajak dalam rangka mempermudah wajib pajak untuk melaporkan pajak menerbitkan modernisasi administrasi perpajakan modern dengan menggunakan teknologi informasi yang juga mengikuti kemajuan teknologi dengan pelayanan berbasis $e$-system seperti e-registration, e-spt, e-filing, e-billing yang diharapkan dapat meningkatkan mekanisme kontrol dan pelaporan yang lebih efektif. Tujuan di perbaharuinya e-system perpajakan ini dibuat dengan harapan dapat mempermudah wajib pajak untuk melaksanakan kewajiban perpajakannya. Seperti e-registration yang mempermudah pendaftaran NPWP dan pengukuhan pengusaha kena pajak untuk berkonsultasi mengenai pajak melalui online, e-SPT dengan penyampaian SPT dengan program yang telah disediakan oleh Direktorat Jendral Pajak, e-filing dan e-payment yang berguna untuk melaporkan surat pemberitahuan serta pembayaran pajak secara elektronik. Serta tujuan lainya adalah untuk menghemat waktu,mudah,akurat dan tanpa kertas sehingga menghasilkan pelayanan secara efisien dan efektif. Penggunaan e-system ini dikatakan efektif apabila dapat memberikan kemudahan bagi wajib pajak dalam sarana penyampaia , perhitungan, dan pembayaran pajak. Berdasarkan data yang di peroleh dari Direktorat Jendral Pajak Kementerian Keuangan menargetkan 7 juta wajib pajak yang menyelesaikan pelaporan SPT pajak menggunakan sistem pengisian elektronik.

Dewasa ini masih banyak juga usahawan yang belum mempunyai Nomor Pokok Wajib Pajak (NPWP) dan belum dikukuhkan sebagai pengusaha kena pajak (PKP). bukan hanya usahawan saja bahkan karyawan professional juga masih belum taat dalam kegiatan membayar pajak. Hal inilah yang membuat penerimaaan pajak menjadi kurang maksimal padahal potensi pajak dari orang pribadi cukup besar dengan jumlah penduduk Indonesia yang besar dapat memberikan dampak yang signifikan terhadap penerimaan pajak. Hal ini tentu saja harus di barengi dengan pengelolaan administrasi yang baik serta upaya pendidikan untuk membangun kesadaran wajib pajak dalam melaksanakan kewajiban perpajakan, jika masyarakat tidak merasakan manfaat pajak yang di bayarnya maka persepsi masyarakat akan terus bersifat negatif terhadap pemerintah dikarenakan pajak bersifat memaksa sehingga banyak wajib pajak yang tidak melaksanakan kewajiban perpajakanya. masih kurangnya sosialisasi mengenai e-system perpajakan yang terkait dengan fasilitas $e$ - 
registration, e-spt, e-filing, e-billing menyebabkan kurangnya kesadaran masyarakat untuk berpartisipasi dalam usaha untuk meningkatkan pemenuhan kewajiban perpajakan. Hal ini disebabkan oleh pengetahuan sebagian besar wajib pajak tentang $e$-system perpajakan yang masih rendah sehingga menyebabkan kepatuhan masyarakat membayar pajak masih kurang. Hal lain yang sering terjadi juga seperti kendala teknis dalam sistem online dan kurangnya kepedulian masyarakat terhadap masalah perpajakan dengan menggunakan media internet.

\section{KAJIAN TEORI}

Pengertian pajak. Menurut P.J.Andriani yang telah diterjemahkan oleh R.Santoso Brotodiharjo (1991) dalam waluyo (2013), mendefenisikan pajak sebagai:

"Pajak adalah iuran kepada negara (yang dapat dipaksakan) yang terutang oleh wajib membayarnya menurut peraturan-peraturan, dengan tidak mendapat prestasi kembali, yang langsung dapat ditunjuk, dan yang gunanya adalah untuk membiayai pengeluaran-pengeluaran umum berhubung dengan tugas negara yang menyelenggarakan pemerintahan."

Sistem E-registration. Sistem Pendaftaran Wajib Pajak secara Online atau e-Registration adalah system pendaftaran, perubahan data Wajib Pajak dan atau Pengukuhan dan Pencabutan Pengukuhan Pengusaha Kena Pajak melalui sistem yang terhubung langsung secara online dengan Direktorat Jenderal Pajak. Sistem e-Registration merupakan salah satu produk layanan di Direktorat Jenderal Pajak yang digunakan untuk melakukan pendaftaran Wajib Pajak baru yang ingin memperoleh Nomor Pokok Wajib Pajak (NPWP). Sistem e-Registration mulai efektif digunakan sejak tahun 2005, yaitu sejak di terbitkannya Keputusan Direktur Jenderal Pajak Nomor: KEP-173/PJ/2004 tanggal 7 Desember 2004 tentang Tata Cara Pendaftaran dan Penghapusan Nomor Pokok Wajib Pajak serta Pengukuhan dan Pencabutan Pengusaha Kena Pajak dengan Sistem eRegistration yang telah diperbaharui dengan Peraturan Direktur Jenderal Pajak Nomor: PER-24/PJ/2009 tanggal 16 Maret 2009 tentang Tata Cara Pendaftaran Nomor Pokok Wajib Pajak dan atau Pengukuhan Pengusaha Kena Pajak dan Perubahan Data Wajib Pajak dan atau Pengusaha Kena Pajak dengan Sistem e-Registration. Perubahan peraturan dari PER-24/PJ/2009 menjadi PER-38/PJ/2013 membawa perubahan yang cukup signifikan mengenai tata cara pendaftaran dengan Sistem e-Registration, salah satunya yang paling mendasar adalah petugas pajak di Kantor Pelayanan Pajak (KPP) tidak perlu lagi menunggu berkas pendaftaran dari Wajib Pajak untuk melakukan proses validasi NPWP, selain itu juga banyak perubahan-perubahan secara administratif.

Sistem $\boldsymbol{e}$-spt. Dalam mewujudkan sistem administrasi perpajakan modern, pemerintah menyediakan aplikasi yang dapat digunakan oleh wajib pajak untuk melakukan pengisian dan pelaporan SPT secara cepat, tepat dan akurat. Menurut Pandiangan, Liberti (2008:35) yang dimaksud dengan e-SPT adalah penyampaian SPT dalam bentuk digital ke KPP secara elektronik atau dengan menggunakan media komputer, sedangkan pengertian eSPT menurut DJP adalah Surat Pemberitahuan beserta lampiran-lampirannya dalam bentuk digital dan dilaporkan secara elektronik atau dengan menggunakan media komputer yang digunakan untuk membantu wajib pajak dalam melaporkan perhitungan dan pembayaran pajak yang terutang sesuai dengan ketentuan peraturan perundangundangan yang berlaku. 
Menurut Dirjen Pajak Aplikasi e-SPT atau disebut dengan Elektronik SPT adalah aplikasi yang dibuat oleh Direktorat Jenderal Pajak Kementerian Keuangan untuk digunakan oleh Wajib Pajak untuk kemudahan dalam menyampaikan SPT.

Sistem e-filing. E-filing adalah suatu cara penyampaian SPT atau penyampaian Pemberitahuan Perpanjangan SPT Tahunan secara elektronik yang dilakukan secara online yang real time melalui website Direktorat Jendral Pajak atau Penyedia Jasa Aplikasi atau Application Service Provider (ASP). Secara umum, penyampaian SPT atau penyampaian Pemberitahuan Perpanjangan SPT Tahunan secara elektronik melalui E-filing diatur melalui Peraturan Direktur Jenderal Pajak Nomor PER-48/PJ/2011 tentang Perubahan Kedua Atas Peraturan Direktur Jenderal Pajak Nomor PER-19/PJ./2009 Tentang Tata Cara Penerimaan Dan Pengolahan Surat Pemberitahuan Tahunan tanggal 30 Desember 2011.

Secara khusus, penyampaian SPT atau penyampaian Pemberitahuan Perpanjangan SPT Tahunan secara elektronik melalui e-filing pada situs Direktorat Jenderal Pajak diatur melalui Peraturan Direktur Jenderal Pajak Nomor PER-39/PJ/2011 tentang Tata Cara Penyampaian Surat Pemberitahuan Tahunan Bagi Wajib Pajak Orang Pribadi Menggunakan Formulir 1770S atau 1770SS.

Saat ini aplikasi e-fling melalui situs Direktorat Jenderal Pajak baru dapat memfasilitasi pelaporan formulir 1770S dan 1770SS, sedangkan formulir lainnya dapat dilaporkan melalui Penyedia Jasa Aplikasi (Application Service Provider). Wajib Pajak diharuskan memiliki $e$-FIN sebelum dapat menyampaikan SPT atau pemberitahuan perpanjangan SPT Tahunan secara $e$-Filing. Untuk memperoleh $e$-FIN, bagi Wajib Pajak yang akan menyampaikan SPT secara $e$-Filing melalui website Direktorat Jenderal Pajak dapat mengajukan permohonan $e$-FIN ke KPP terdekat, sedangkan bagi bagi Wajib Pajak yang akan menyampaikan SPT secara e-Filing melalui ASP harus mengajukan permohonan $e$-FIN ke KPP tempat Wajib Pajak terdaftar.

Sistem e-billing. Saat ini Wajib Pajak dapat lebih mudah dalam memenuhi kewajiban perpajakan dengan memanfaatkan fasilitas-fasilitas elektronik yang telah disediakan Direktorat Jenderal Pajak. Salah satu fasilitas tersebut adalah sistem pembayaran $e$-biling. Sistem pembayaran pajak secara elektronik adalah bagian dari sistem Penerimaan Negara secara elektronik yang diadministrasikan oleh Direktorat Jenderal Pajak dengan menerapkan sistem e-biling. E-biling adalah metode pembayaran elektronik dengan menggunakan Kode Billing.

Wajib Pajak dapat melakukan pembayaran atau penyetoran pajak dengan sistem pembayaran pajak secara elektronik. Pembayaran atau penyetoran pajak meliputi seluruh jenis pajak, kecuali: (1) Pajak dalam rangka impor yang diadministrasikan pembayarannya oleh Biller Direktorat Jenderal Bea dan Cukai, dan (2) Pajak yang tata cara pembayarannya diatur secara khusus.

Pembayaran atau penyetoran pajak tersebut, meliputi pembayaran dalam mata uang Rupiah dan Dollar Amerika Serikat. Pembayaran dalam mata uang Dollar Amerika Serikat hanya dapat dilakukan untuk Pajak Penghasilan Pasal 25, Pajak Penghasilan Pasal 29 dan Pajak Penghasilan yang bersifat Final yang dibayar sendiri oleh Wajib Pajak yang memperoleh izin untuk menyelenggarakan pembukuan dengan menggunakan bahasa Inggris dan mata uang Dollar. 
Amerika Serikat. Transaksi pembayaran/penyetoran pajak secara elektronik, dilakukan melalui Bank atau Pos Persepsi dengan menggunakan Kode Billing. Kode Billing adalah kode identifikasi yang diterbitkan melalui Sistem Billing atas suatu jenis pembayaran atau setoran yang akan dilakukan Wajib Pajak

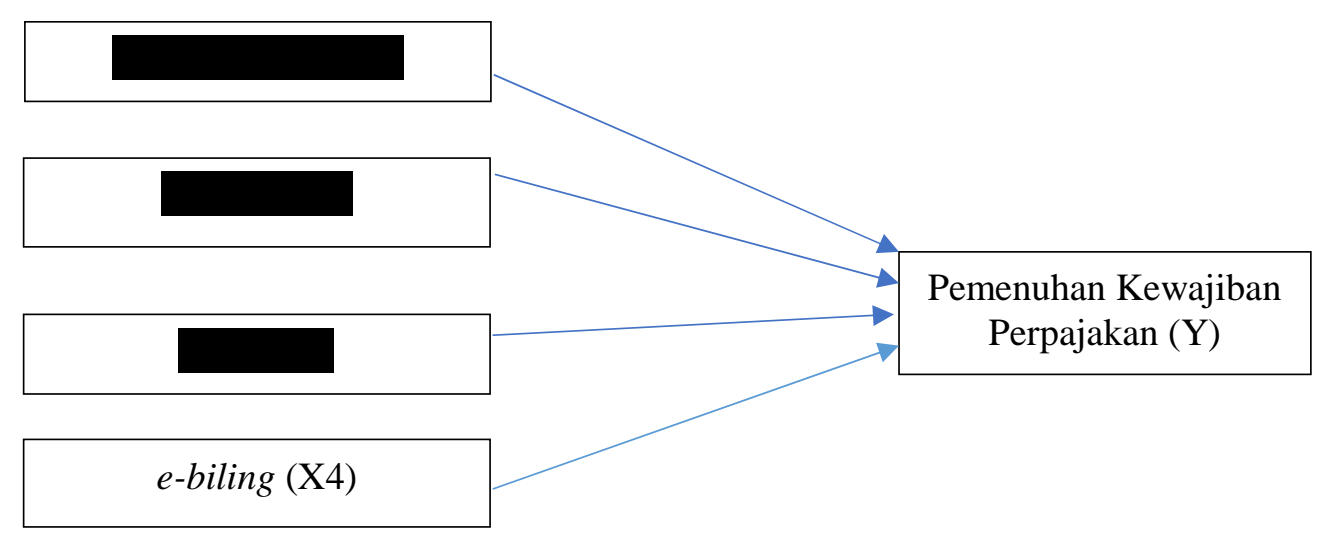

Gambar 1. Bagan Perumusan hipotesis

\section{METODE}

Populasi dan Teknik Pemilihan Sampel. Populasi adalah wilayah generalisasi yang terdiri atas: objek atau subjek yang mempunyai kualitas dan karakteristik tertentu yang ditetapkan oleh peneliti untuk dipelajari dan kemudian ditarik kesimpulannya (Sugiyono, 2009: 61). Populasi bukan sekedar jumlah yang ada pada objek atau subjek yang dipelajari, tetapi meliputi seluruh karakteristik atau sifat yang dimiliki oleh subjek atau objek yang diteliti sedangkan sampel adalah bagian dari jumlah dan karakteristik yang dimiliki oleh populasi. Adapun populasi pada penelitian ini adalah wajib pajak pribadi di KPP Pratama Kebayoran Baru Tiga Jakarta Selatan untuk tahun 2016.

Tabel 1. Proses Seleksi Sampel

\begin{tabular}{|c|c|}
\hline Keterangan & Jumlah kuesioner \\
\hline Kuesioner yang dibagikan & 100 \\
\hline Kuisoner yang dikembalikan & 100 \\
\hline Kuisoner yang tidak lengkap & 0 \\
\hline $\begin{array}{l}\text { Kuisoner yang dapat digunakan untuk } \\
\text { pengolahan data lebih lanjut }\end{array}$ & 100 \\
\hline
\end{tabular}

Definisi Operasional variable. Variabel Independen (Variabel bebas) penelitian yang digunakan oleh peneliti yaitu variabel $e$-registration sebagai X1, variabel $e$-spt sebagai $\mathrm{X} 2$, variabel $e$-filling sebagai $\mathrm{X} 3$, variabel $e$-billing sebagai $\mathrm{X} 4$, adapun variabel dependen yang digunakan oleh peneliti yaitu kewajiban perpajakan wajib pajak pribadi sebagai $Y$. 
Tabel 2. Operasional Variabel

\begin{tabular}{|c|c|c|c|}
\hline Variabel & $\begin{array}{c}\text { Konsep } \\
\text { variabel }\end{array}$ & Indikator Independen & $\begin{array}{c}\text { Skala } \\
\text { Pengukuran }\end{array}$ \\
\hline $\begin{array}{l}\text { Penerapan } e- \\
\text { registration } \\
(\mathrm{X} 1) \\
\text { Pujiani \& Effendi } \\
(2009)\end{array}$ & $\begin{array}{l}\text { Wajib Pajak } \\
\text { mendaftarkan } \\
\text { diri untuk } \\
\text { memperoleh } \\
\text { NPWP secara } \\
\text { online }\end{array}$ & $\begin{array}{l}\text { - Kesadaran mendaftarkan NPWP } \\
\text { - Pengetahuan terhadap peraturan } \\
\text { perpajakan yang berlaku } \\
\text { - Efektifitas terhadap system } \\
\text { perpajakan }\end{array}$ & Ordinal \\
\hline $\begin{array}{l}\text { Penerapan } e \text { - } \\
\text { spt }(\mathrm{X} 2) \text { Maya } \\
\& \text { Sherly } \\
(2015)\end{array}$ & $\begin{array}{l}\text { Wajib Pajak } \\
\text { dapat mengisi } \\
\text { dan menghitung } \\
\text { SPT secara } \\
\text { online }\end{array}$ & $\begin{array}{l}\text { - Pengaruh } \\
\text { kemudahan } \\
\text { - Pengaruh } \\
\text { manfaat } \\
\text { - pelaporan }\end{array}$ & Ordinal \\
\hline $\begin{array}{l}\text { Penerapan } e \text { - } \\
\text { filing (X3) Mirza } \\
\text { \& Rizki (2015) }\end{array}$ & $\begin{array}{l}\text { Wajib pajak } \\
\text { dapat } \\
\text { melaporkan } \\
\text { SPT pajak } \\
\text { secara online }\end{array}$ & $\begin{array}{l}\text { - Efektifitas system } \\
\text { perpajakan } \\
\text { - Kelayakan system } \\
\text { perpajakan } \\
\text { - Pelaporan pajak } \\
\text { menggunakan } e \text {-filing }\end{array}$ & Ordinal \\
\hline $\begin{array}{l}\text { Penerapan } e- \\
\text { biling }(\mathrm{X} 4) \\
\text { Yusup, } \\
\text { Hardiyana, \& } \\
\text { Sirdata (2015) }\end{array}$ & $\begin{array}{l}\text { Pengaruh } \\
\text { Kebijakan } \\
\text { system } \\
\text { pembayaran } \\
\text { pajak secara } \\
\text { online }\end{array}$ & $\begin{array}{l}\text { - Efektifitas penggunaan } \\
\text { dalam pembayaran pajak } \\
\text { - Kondisi penggunaan dalam } \\
\text { pembayaran pajak }\end{array}$ & Ordinal \\
\hline $\begin{array}{l}\text { Kewajiban } \\
\text { Perpajakan (Y) } \\
\text { Supadmi \& } \\
\text { Andrayani } \\
(2010)\end{array}$ & $\begin{array}{l}\text { Pengetahuan } \\
\text { wajib pajak } \\
\text { dalam } \\
\text { memenuhi } \\
\text { kewajiban } \\
\text { perpajakanya }\end{array}$ & $\begin{array}{l}\text { - Kewajiban menghitung } \\
\text { perpajakan } \\
\text { - Kewajiban } \\
\text { memperhitungkan } \\
\text { - Kewajiban membayar } \\
\text { - Kewajiban melapor } \\
\text { - Kewajiban menyetor pajak }\end{array}$ & Ordinal \\
\hline
\end{tabular}

Model Regresi penelitian. Menurut Priyatno (2010,:61), analisis regresi linier berganda adalah hubungan secara linier antara dua veriabel atau lebih variabel independen (X) dengan variabel dependen (Y). Berikut adalah model penelitian yang akan digunakan dalan penelitian ini sebagai tujuan pengujian hipotesis:

$$
\mathrm{Y}=\mathrm{a}+\mathrm{b}_{1} \mathrm{X}_{1}+\mathrm{b}_{2} \mathrm{X}_{2}+\mathrm{b}_{3} \mathrm{X}_{3}+\mathrm{b}_{4} \mathrm{X}_{4}+\mathrm{e}
$$


Dimana: $\mathrm{Y}=$ Kewajiban perpajakan; $\mathrm{a}=$ konstanta; b1, b2, b3, b4 = koefisien regresi $\mathrm{X} 1=e$-registration; $\mathrm{X} 2=e$-spt: $\mathrm{X} 3=e$-filing;

$\mathrm{X} 4=e$-biling; $\mathrm{e}=$ Variabel gangguan

\section{HASIL DAN PEMBAHASAN}

Hasil pengujian multikolinieritas menggunakan Variance Inflator Factor (VIF) dari pengujian SPSS 20. Batas VIF adalah 5, apablia hasil analisis menunjukkan bahwa VIF di bawah nilai 5 maka tidak terjadi multikolinieritas. Sebaliknya jika hasil VIF berada di atas nilai 5 maka terjadi multikolinieritas.

Tabe 3. Multikolinieritas

\begin{tabular}{lcc}
\hline Model & \multicolumn{2}{c}{ Collinearity Statistics } \\
\cline { 2 - 3 } & Tolerance & VIF \\
(Constant) &, 708 & 1,412 \\
Penerapan e-Registration &, 796 & 1,256 \\
1 Penerapan e-SPT &, 682 & 1,466 \\
Penerapan e-Filing &, 646 & 1,548 \\
Penerapan e-Billing & & \\
\hline
\end{tabular}

Dari Tabel di atas, dapat diketahui bahwa VIF untuk varibel $e$-registration (X1) sebesar 1,412, variabel e-spt (X2) sebesar 1,256, variabel e-filing (X3) sebesar 1,466, dan variabel $e$-billing $(\mathrm{X} 4)$ sebesar 1,548 . Hal ini berarti variabel - variabel dalam penelitian ini tidak memiliki masalah multikolinieritas karena nila VIF semua variabel independen tersebut di bawah 5 .

Uji Heteroskedastisitas. Uji heteroskedastisitas digunakan untuk mengetahui ada atau tidaknya penyimpangan asumsi klasik heteroskedastisitas yang berupa ketidaksamaan varian dari residual untuk semua pengamatan pada model regresi. Prasyarat yang haris dipenuhi dalam model regresi adalah tidak adanya gejala heteroskedastisitas. Metode pengujian yang digunakan adalah dengan melihat grafik plot hasil analisis tersebut yang dapat dilihat dari Gambar 2.

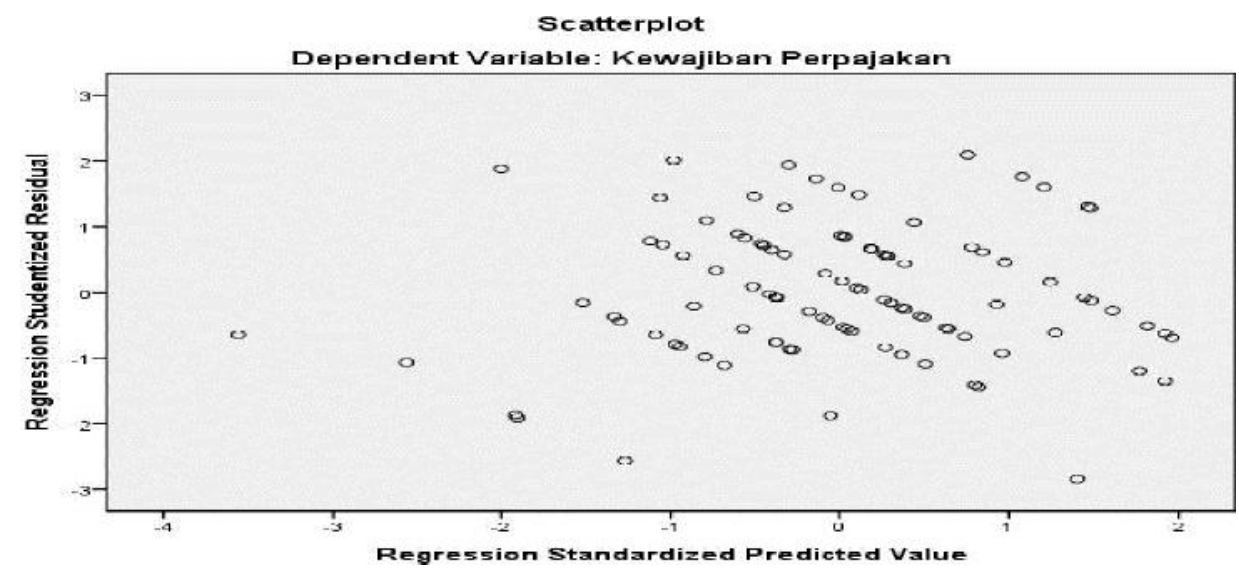

Gambar 2. Hasil Pengujian Heteroskedastisitas 
Dari hasil uji asumsi heteroskedastisitas melalui scatter plot dapat dilihat bahwa titik titik menyebar di atas dan di bawah angka nol dari sumbu y tanpa membentuk suatu pola. Maka model regresi memiliki kesamaan varians atau tidak terjadi heteroskedastisitas.

Uji Normalitas. Menurut Priyatno (2010, 71), uji normalitas digunakan untuk mengetahui apakah populasi berdistribusi normal atau tidak. Model regresi yang baik memiliki distribusi data yang normal atau mendekati normal. Uji normalitas dalam penelitian ini menggunakan uji Kolmogorov-smirnov. Dasar pengambilan keputusa berdasarkan nilai p-value pada kolom Asymp. Sig(2-tailed) yang dihasilkan, dengan ketentuan sebagai berikut : 1) Jika p-value pada kolom Asymp, Sig(2-tailed) $\leq 0,05$ maka Ho ditolak dan Ha diterima. Dengan kata lain, data tidak terdistribusi normal. 2) Jika pvalue pada kolom Asymp, Sig(2-tailed) > 0,05 maka Ho diterima dan Ha ditolak. Dengan kata lain, data terdistribusi normal.

Tabel 4. One-Sample Kolmogorov-Smirnov Test

\begin{tabular}{llr}
\hline & & Unstandardized Residual \\
\hline $\mathrm{N}$ & Mean & 100 \\
& & $0 \mathrm{E}-7$ \\
Normal Parameters & a,b & \\
& Std. Deviation & 1,43087287 \\
& Absolute &, 079 \\
Most Extreme & Pocitive & 070 \\
Differences & Negative &,- 060 \\
$\begin{array}{l}\text { Kolmogorov- } \\
\begin{array}{l}\text { Smirnov Z } \\
\text { Asymp. Sig. (2- } \\
\text { tailed) }\end{array}\end{array}$ & &, 786 \\
\hline
\end{tabular}

a. Test distribution is Normal.

b. Calculated from data.

Sumber: Data Primer yang diolah SPSS, 2016

Dari Tabel 4 dapat dilihat pada kolom Kolmogorov-smirnov dan dapat diketahui bahwa nilai signikasnsi untuk seluruh variabel yaitu 0,567 lebih besar dari 0,05. Maka dapat disimpulkan bahwa populasi data seluruh variabel dalam penelitian ini berdistribusi normal. 
Pengujian Hipotesis

Tabel 5. Tabel Koefisien

Coefficients $^{\mathrm{a}}$

\begin{tabular}{lccccc}
\hline Model & \multicolumn{2}{c}{$\begin{array}{c}\text { Unstandardized } \\
\text { Coefficients }\end{array}$} & $\begin{array}{l}\text { Standardized } \\
\text { Coefficients }\end{array}$ & $\mathrm{t}$ & Sig. \\
\cline { 2 - 4 } & $\mathrm{B}$ & Std. Error & Beta & & \\
\hline (Constant) & 2,380 & 1,667 & & 1,427 &, 157 \\
Penerapan e- &, 187 &, 057 & & 3,256 &, 002 \\
$\quad$ Registration &, 160 &, 056 & & 2,841 &, 005 \\
$\quad$ Penerapan e-SPT &, 213 &, 069 & & 3,106 &, 003 \\
$\mathbf{1} \quad$ Penerapan e- &, 252 &, 075 & & 3,350 &, 001 \\
$\quad$ & & &, 260 & & \\
$\quad$ Filing & & &, 214 & & \\
Penerapan e- & & &, 253 & & \\
$\quad$ Billing & & &, 280 & & \\
\hline
\end{tabular}

a. Dependent Variable: Kewajiban Perpajakan

Sumber: Data Primer yang diolah SPSS, 2016

Berdasarkan Tabel 5, maka dapat dibuat persamaan regresi sebagai berikut:

$$
\begin{gathered}
\mathrm{Y}=\mathrm{a}+\mathrm{b} 1 \mathrm{X} 1+\mathrm{b} 2 \mathrm{X} 2+\mathrm{b} 3 \mathrm{X} 3+\mathrm{b} 3 \mathrm{X}+e \\
\mathrm{Y}=2,380+0,187 \mathrm{X} 1+0.160 \mathrm{X} 2+0.213 \mathrm{X} 3+0,252 \mathrm{X} 4+e
\end{gathered}
$$

Hasil pengujian Hipotesis pertama. Maka hipotesis pertama penelitian ini menyatakan bahwa, e-registration (X1) berpengaruh terhadap pemenuhan kewajiban perpajakan wajib pajak pribadi. Berdasarkan hasil output yang terdapat pada Tabel 5 terlihat bahwa variabel sikap (X1) memiliki sig. sebesar 0,002. Nilai signifikansi ini lebih kecil dari 0,05 maka H1 diterima yang berarti Penerapan e-registration berpengaruh secara signifikan terhadap Pemenuhan kewajiban perpajakan wajib pajak pribadi.

Hasil penelitian ini tidak sama dengan hasil penelitian terdahulu yang dilakukan oleh Pujiani \& effendi (2009), yang menyatakan penggunaan e-registration tidak berpengaruh positif dan signifikan terhadap kewajiban perpajakan.

Hasil pengujian Hipotesis kedua. Hipotesis kedua penelitian ini menyatakan, bahwa penerapan $e$-spt (X2) berpengaruh terhadap pemenuhan kewajiban perpajakan wajib pajak pribadi. Berdasarkan hasil output yang terdapat pada Tabel 5 terlihat bahwa variabel $e$-spt (X2) memiliki sig. sebesar 0,005. Nilai signifikansi ini lebih kecil dari 0,05 maka H2 diterima yang berarti penerapan $e$-spt berpengaruh secara signifikan terhadap pemenuhan kewajiban perpajakan wajib pajak pribadi.

Hasil penelitian ini sejalan dengan hasil penelitian terdahulu yang dilakukan oleh Novi \& Maria (2014), yang menyatakan pengaruh penerapan $e$-spt berpengaruh secara signifikan terhadap pemenuhan kewajiban perpajakan wajib pajak pribadi.

Hasil pengujian Hipotesis ketiga. Hipotesis ketiga penelitian ini menyatakan bahwa, penerapan e-filing (X3) berpengaruh terhadap pemenuhan kewajiban perpajakan wajib pajak pribadi. Berdasarkan hasil output yang terdapat pada Tabel 5 terlihat bahwa variabel e-filing (X3) memiliki sig. sebesar 0,003. Nilai signifikansi ini lebih kecil dari 0,05 maka H3 diterima yang berarti penerapan e-filing berpengaruh secara signifikan terhadap 
pemenuhan kewajiban perpajakan wajib pajak pribadi. Hasil penelitian ini sejalan dengan hasil penelitian terdahulu yang dilakukan oleh Mirza \& Rizki (2015), yang menyatakan pengaruh sistem $e$-filing berpengaruh secara signifikan terhadap pemenuhan kewajiban perpajakan dan kepuasan wajib pajak.

Hasil pengujian Hipotesis keempat. Hipotesis keempat penelitian ini menyatakan bahwa, penerapan e-billing (X4) berpengaruh terhadap pemenuhan kewajiban perpajakan wajib pajak pribadi. Berdasarkan hasil output yang terdapat pada tabel 4.24 terlihat bahwa variabel e-billing (X4) memiliki sig. sebesar 0,001. Nilai signifikansi ini lebih kecil dari 0,05 maka $\mathrm{H} 4$ diterima yang berarti penerapan e-billing berpengaruh secara signifikan terhadap pemenuhan kewajiban perpajakan wajib pajak pribadi.

Pembahasan. Penelitian ini menggunakan sampel sebanyak 100 Wajib Pajak Pribadi yang disebarkan ke 100 Wajib Pajak KPP Pratama Kebayoran Baru Tiga Jakarta Selatan. Variabel yang diteliti, yaitu variabel independen dan variabel dependen. Variabel independen dalam penelitian ini adalah penerapan e-registration, e-spt, e-filing, e-billing. sedangkan variabel dependennya adalah kewajiban perpajakan Wajib Pajak Pribadi. Penelitian ini bertujuan untuk untuk mengetahui pengaruh penerapan e-registration, $e$-spt, $e$-filing, e-billing terhadap pemenuhan kewajiban perpajakan Wajib Pajak Pribadi pada Kantor Pelayanan Pajak Pratama Kebayoran Baru Tiga Jakarta Selatan. Peneliti menggunakan uji statisitk dimulai dengan pengujian statistik deskriptif selanjutnya uji asumsi klasik dan yang terakhir pengujian hipotesis untuk mengetahui bagaimana kelayakan model regresi yang digunakan untuk penelitian. Pengolahan data serta pengujian hipotesis dalam penelitian ini dilakukan dengan menggunakan software SPSS v.22 for windows.

Berdasarkan pengujian hipotesis yang telah dilakukan, maka dapat disimpulkan sebagai berikut:

1. Penerapan e-registration memiliki pengaruh positif yang signifikan terhadap kewajiban perpajakan wajib pajak pribadi karena variable e-registration (X1) memiliki sig. Sebesar 0,002 yang lebih kecil dari 0,05. Hasil penelitian ini tidak sama dengan hasil penelitian terdahulu yang dilakukan oleh Pujiani \& effendi (2009), yang menyatakan penggunaan e-registration tidak berpengaruh positif dan signifikan terhadap kewajiban perpajakan.

2. Penerapan e-spt memiliki pengaruh positif yang signifikan terhadap kewajiban perpajakan wajib pajak pribadi karena variabel e-spt (X2) memiliki sig. Sebesar 0,005 yang lebih kecil dari 0,05 . Hasil penelitian ini sejalan dengan hasil penelitian terdahulu yang dilakukan oleh Novi \& Maria (2014), yang menyatakan pengaruh penerapan e-spt berpengaruh secara signifikan terhadap pemenuhan kewajiban perpajakan wajib pajak pribadi.

3. Penerapan e-filing memiliki pengaruh positif yang signifikan terhadap kewajiban perpajakan wajib pajak pribadi karena variabel e-filling (X3) memiliki sig.Sebesar 0,003 kurang dari 0,05 . Hasil penelitian ini sejalan dengan hasil penelitian terdahulu yang dilakukan oleh Mirza \& Rizki (2015), yang menyatakan pengaruh sistem e-filing berpengaruh secara signifikan terhadap pemenuhan kewajiban perpajakan dan kepuasan wajib pajak.

4. Penerapan e-billing memiliki pengaruh positif yang signifikan terhadap kewajiban perpajakan wajib pajak pribadi karena variabel e-billing memiliki sig. Sebesar 0,001 lebih kecil dari 0,05 . Hasil ini sejalan dengan hasil penelitian yang dilakukan oleh 
Arthur \& Helen (2016), yang menyatakan pengaruh sistem e-billing berpengaruh secara signifikan terhadap pemenuhan kewajiban perpajakan dan kepuasan wajib pajak.

\section{DAFTAR RUJUKAN}

Anastasia dan Saroh (2012) "Pengaruh Efektivitas penyuluhan, Penerapan Aplikasi Elektronik Perpajakan dan Pemeriksaan Pajak terhadap Tingkat Kepatuhan Pemenuhan Kewajiban perpajakan (Studi Pada KPP Pratama Surabaya Wonocolo)", Surabaya. Skripsi, Ps Perpajakan.

Mardiasmo (2013) Perpajakan. Buku 1. Edisi revisi. Jakarta: Andi publisher Undang-Undang Nomor 28 Tahun 2007 Tentang Ketentuan Umum Perpajakan

Novi dan Maria (2014) "Pengaruh Penerapan e-spt Terhadap Kepatuhan Wajib Pajak Badan Dalam Melaporkan SPT". Skripsi, Malang. Ps Perpajakan.

Mohammad Zain, (2008) Manajemen Perpajakan, Edisi 3, Jakarta: Salemba Empat.

Maya dan Sherly (2015) "Pengaruh Manfaat Dan Kemudahan e-spt Terhadap Pelaporan e-spt Oleh Wajib Pajak Pribadi Pada KPP Pratama Bitung”. Jurnal, Bitung. ISSN 2303-1174.

Mirza dan Rizki (2015) "Analisis Efektivitas dan Kelayakan Sistem Pelaporan Pajak Menggunakan e-filling Terhadap kepuasan Wajib Pajak". Skripsi, Malang. Ps Perpajakan.

Pandiangan, Liberti, (2013) Modernisasi dan Reformasi Pelayanan Perpajakan Berdasarkan Undang-Undang Terbaru. Jakarta: PT Elex Media Komputindo,

Pujiani dan Effendi (2009) "Analisis Efektivitas penggunaan E-system Terhadap Penerimaan Pajak Di KPP Pratama Palembang Ilir Timur" . Palembang. STIE MDP.

Priyatno dan Duwi (2010) Teknik mudah dan cepat melakukan Analisis Data Penelitian dengan SPSS. Yogakarta: Gava Media

Tata Cara Pendaftaran Menggunakan e-registration. www.pajak.go.id Tata Cara Pembayaran melalui e-billing.www.pajak.go.id

Peraturan Direktur Jendral Pajak Nomor PER-48/PJ/2011 tentang Tata Cara Penerimaan Dan Pengolahan Surat Pemberitahuan Tahunan.

Peraturan Direktur Jendral Pajak Nomor PER-38/PJ/2013 Tentang Tata Cara Pendaftaran dengan Sistem e-registration.

Peraturan Direktur Jendral Pajak Nomor PER-01/PJ/2016 tentang Tata Cara Penerimaan dan Pengolahan SPT Tahunan

Resmi, Siti (2016) Perpajakan Teori dan Kasus. Buku 1. Edisi 9. Jakarta: Salemba empat

Siti Kurnia Rahayu (2011) Perpajakan Indonesia Konsep dan Aspek Formal. Yogyakarta: Graha Pustaka

Supadmi dan Andrayani (2010) "Analisis Tingkat Pemahaman Wajib Pajak Orang Pribadi Pada Pelaksanaan Self Assesment Dalam Melaksanakan Kewajiban Perpajakan". Denpasar. Jurnal akuntansi.

Waluyo (2013) Perpajakan Indonesia. Buku 1. Edisi 11: Salemba empat

Yusup, Hardiyana, dan Sirdata (2015) "Penerimaan Penggunaan Model Adopsi e-billing". Bandung. E-ISSN 2350-8442. 